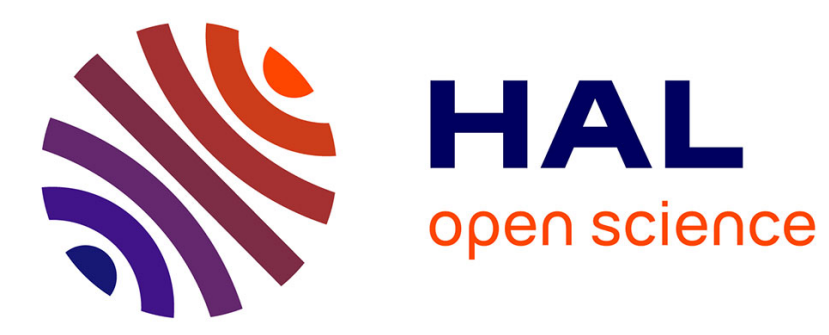

\title{
Suboptimal use of statins at treatment initiation
}

Vesa Kiviniemi, Piia Peura, Arja Helin-Salmivaara, Jaana E. Martikainen, Juha Hartikainen, Risto Huupponen, Maarit Jaana Korhonen

\section{To cite this version:}

Vesa Kiviniemi, Piia Peura, Arja Helin-Salmivaara, Jaana E. Martikainen, Juha Hartikainen, et al.. Suboptimal use of statins at treatment initiation. European Journal of Clinical Pharmacology, 2011, 67 (9), pp.971-973. 10.1007/s00228-011-1037-0 . hal-00685388

\section{HAL Id: hal-00685388 \\ https://hal.science/hal-00685388}

Submitted on 5 Apr 2012

HAL is a multi-disciplinary open access archive for the deposit and dissemination of scientific research documents, whether they are published or not. The documents may come from teaching and research institutions in France or abroad, or from public or private research centers.
L'archive ouverte pluridisciplinaire HAL, est destinée au dépôt et à la diffusion de documents scientifiques de niveau recherche, publiés ou non, émanant des établissements d'enseignement et de recherche français ou étrangers, des laboratoires publics ou privés. 
Vesa Kiviniemi, LicSc ${ }^{1}$, Piia Peura, MSc (Pharm) ${ }^{1}$, Arja Helin-Salmivaara, MD, $\mathrm{PhD}^{2,3}$, Jaana E

Martikainen, LicSc (Pharm) ${ }^{4}$, Juha Hartikainen, Professor ${ }^{5,6}$, Risto Huupponen, Professor ${ }^{2,7}$, Maarit Jaana Korhonen, PhD, LicSc (Pharm) ${ }^{2}$

\section{Suboptimal use of statins at treatment initiation}

${ }^{1}$ Finnish Medicines Agency

${ }^{2}$ Department of Pharmacology, Drug Development and Therapeutics, University of Turku, Finland

${ }^{3}$ Unit of General Practice, Hospital District of Helsinki and Uusimaa, Helsinki, Finland

${ }^{4}$ Research Department, Social Insurance Institution, Helsinki, Finland

${ }^{5}$ School of Medicine, University of Eastern Finland, Kuopio, Finland

${ }^{6}$ Heart Center, Kuopio University Hospital, Kuopio, Finland

${ }^{7}$ Unit of Clinical Pharmacology, Turku University Hospital, Turku, Finland

Corresponding author:

Maarit Jaana Korhonen

Department of Pharmacology, Drug Development and Therapeutics, University of Turku, 20014

Turun yliopisto, Finland

Tel. +358403572081

Fax. +35817162424

E-mail: maarit.korhonen@utu.fi

Word count: 600 
The benefits of statins in reducing the risk of cardiovascular (CV) events in various high-risk patient groups are well-established [1-2]. Recently, more intensive versus less intensive statin therapy has been suggested to reduce the event rates further [3]. Despite the widespread and increasing use of statins [4-5], the above benefits may be diluted due to prescription of doses lower than those shown to be effective in randomized trials [6-8].

Finland, as many other countries, has implemented policies to contain statin costs [9]. Beginning in October 2006, reimbursement of the most expensive statins, atorvastatin and rosuvastatin, was restricted to treatment of severe lipid metabolism disorders in high-risk patients when less expensive statins were ineffective or not tolerated. We sought to characterize new statin users in the fall 2007, approximately one year after the restriction, with respect to the type and dose of the initial statin and CV risk status. Additionally, the initiators were followed up for one year since initiation, for detecting potential changes in the therapy.

Using the Prescription Register maintained by the Social Insurance Institution of Finland (SII) [10], a cohort of individuals aged 18 years or older purchasing statins for the first time between 1 September and 31 December 2007 was identified. Initiators had no statin purchases during the 3 years preceding the cohort entry. Individuals who were institutionalized permanently or died within one year following initiation and those using lipid modifying drugs (World Health Organization Anatomical Therapeutic Chemical classification code C10) other than statins (C10AA) at the cohort entry were excluded. Initiators' CV risk status was classified as high, moderate, or low based on diagnostic information extracted from the SII Special Reimbursement Register and purchases of cardiovascular drugs during the preceding year (Table 1). 
Statin therapy was typically initiated with simvastatin ( $94 \%$ of the cohort), using 10 or 20 -mg tablets (Table 1). Only every fifth simvastatin initiator received $40-\mathrm{mg}$ tablets and $0.1 \%$ 80-mg tablets. Atorvastatin was most commonly initiated with 10 or 20 -mg tablets. Almost one third of the cohort was classified as having high CV risk. Of those with high CV risk, $20 \%$ initiated with 10-mg and $48 \%$ with $20-\mathrm{mg}$ simvastatin tablets, and additional $3 \%$ with other low-potent statin doses [11]. Of all simvastatin initiators, $20 \%$ switched to another dose or to another lipid-lowering medication within one year following initiation, $4 \%$ switching to atorvastatin or rosuvastatin. Among those who initiated with rosuvastatin, atorvastatin, pravastatin, and fluvastatin, the proportions of those switching dose or medication were 19, 29,31, and 34\%, respectively. Between 9 and $14 \%$ of the initiators purchased only one prescription during the first year.

In compliance with the reimbursement restriction [9], a vast majority of new statin users in the fall 2007 in Finland were prescribed simvastatin. However, potential underdosing at initiation was common, even among patients with high $\mathrm{CV}$ risk. A considerable proportion of those initiating with less potent doses also remained at the initial dose after one year. Furthermore, the wholesale statistics show that, of all statin tablets sold in Finland in 2010, 21\% were 10-mg and 49\% 20-mg simvastatin tablets [12]. That is, most simvastatin users in Finland still receive doses lower than the 40-mg dose used in many clinical trials $[2,13]$ and recommended by current clinical guidelines [1415]. While this study has limitations due to the reliance on the SII data on drug use and comorbidities, the results support the notion that potential benefits of statin therapy may be compromised due to low doses prescribed at the initiation and during the subsequent year.

NOTE: The results of this study have been previously published in the Finnish Medical Journal [16].

\section{Acknowledgements}


This study was funded by a grant (October 26, 2007) from the Social Insurance Institution of Finland (Maarit Jaana Korhonen and Arja Helin-Salmivaara).

\section{Conflict of interest}

Piia Peura has participated in a research project on cost-effectiveness of statins funded by Astra Zeneca and received a fee for consulting from ESiOR Oy. The other authors declare that they have no conflict of interest.

\section{References}

1 Brugts JJ, Yetgin T, Hoeks SE, et al (2009) The benefits of statins in people without established cardiovascular disease but with cardiovascular risk factors: meta-analysis of randomised controlled trials. Br Med J 338:b2376

2 Heart Protection Study Collaborative Group (2002) MRC/BHF Heart Protection Study of cholesterol lowering with simvastatin in 20536 high-risk individuals: a randomised placebocontrolled trial. Lancet 360:7-22

3 Cholesterol Treatment Trialists' Collaboration (2010) Efficacy and safety of more intensive lowering of LDL cholesterol: a meta-analysis of data from 170000 participants in 26 randomised trials. Lancet 376:1670-1681 
4 Walley T, Foliono-Gallo P, Stephens P, van Ganse E. (2005) Trends in prescribing and utilization of statins and other lipid lowering drugs across Europe 1997-2003. Br J Clin Pharmacol 60:543-551.

5 Ruokoniemi P, Helin-Salmivaara A, Klaukka T, et al (2008) Shift of statin use towards the elderly in 1995-2005: a nation-wide register study in Finland. Br J Clin Pharmacol 66:405-410.

6 Mantel-Teeuwisse AK, Kungel O, Schalekamp T et al (2005) Suboptimal choices and dosing of statins at start of therapy. Br J Clin Pharmacol 60:83-89

7 Gislason GH, Rasmussen JN, Steen ZA et al (2007) Long-term compliance with beta-blockers, angiotensin-converting enzyme inhibitors, and statins after acute myocardial infarction. Eur Heart J 27:1153-1158

8 Geleedst-De Vooght M, Maitland-van der Zee AH, Schalekamp T et al (2010) Statin prescribing in the elderiy in the Netherlands. A pharmacy database time trend study. Drugs Aging 27:589-596.

9 Martikainen JE, Saastamoinen LK, Korhonen MJ, et al (2010) Impact of restricted reimbursement on the use of statins in Finland. A register-based study. Med Care 48:761-766

10 Furu K, Wettermark B, Andersen M, et al (2009) The Nordic countries as a cohort for pharmacoepidemiological research. Basic Clin Pharmacol Toxicol 106:86-94 
11 Law MR, Wald NJ, Rudnicka AR (2003) Quantifying effect of statins on low density lipoprotein cholesterol, ischaemic heart disease, and stroke: systematic review and meta-analysis. Br Med J 326(7404):1423-1427

12 SLD Pharma (2010) Finnish Pharmaceutical Data Ltd. Statistics 01/2010-11/2010.

13 Scandinavian Simvastatin Survival Study Group (1994) Randomised trial of cholesterol lowering in 4444 patients with coronary heart disease: the Scandinavian Simvastatin Survival Study (4S). Lancet 344:1383-138

14 Working group set up by the Finnish Medical Society Duodecim and the Finnish Society of Internal Medicine (2009) Dyslipidaemias (online). Current Care guideline. Helsinki: Finnish Medical Society Duodecim. Available online at: www.kaypahoito.fi. Accessed 1 March, 2010

15 Smulders YM. Burgers JS. Scheltens T. et al. (2008) Clinical practice guideline for cardiovascular risk management in the Netherlands. Neth J Med 66 (4): 169-174

16 Kiviniemi V, Peura P, Helin-Salmivaara A et al (2011) Statiinihoito aloitetaan simvastatiinilla pienin annoksin. Suom Lääkäril 66:568-571 [in Finnish] 
Table 1 Characteristics of statin initiators and treatment changes during the first year following initiation

\begin{tabular}{|c|c|c|c|c|c|c|c|c|}
\hline Characteristic & $\begin{array}{c}\text { Simvastatin } \\
10 \mathrm{mg} \\
n=6,418 \\
(23.9) \\
\end{array}$ & $\begin{array}{c}\text { Simvastatin } \\
20 \mathrm{mg} \\
n=14,002 \\
(52.1) \\
\end{array}$ & $\begin{array}{c}\text { Simvastatin } \\
40 \mathrm{mg} \\
n=4,916 \\
(18.5) \\
\end{array}$ & $\begin{array}{c}\text { Fluvastatin } \\
n=529 \\
(2.0) \\
\end{array}$ & $\begin{array}{c}\text { Atorvastatin } \\
\begin{array}{c}n=408 \\
(1.5)\end{array}\end{array}$ & $\begin{array}{c}\text { Rosuvastatin } \\
n=269 \\
(1.0) \\
\end{array}$ & $\begin{array}{c}\text { Pravastatin } \\
n=253 \\
(0.9) \\
\end{array}$ & $\begin{array}{c}\text { Any statin } \\
n=26,862 \\
(100.0)\end{array}$ \\
\hline Age. mean $( \pm \mathrm{SD})$, years & $61.9(12.0)$ & $60.4(11.8)$ & $60.4(11.8)$ & $60.6(11.4)$ & $59.2(11.6)$ & $57.2(11.8)$ & $60.9(11.9)$ & $60.7(11.8)$ \\
\hline Male & 42.7 & 51.2 & 63.3 & 47.4 & 62.0 & 57.2 & 48.2 & 51.5 \\
\hline \multicolumn{9}{|l|}{ Initial statin dose } \\
\hline $10 \mathrm{mg}$ & 100.0 & - & - & - & 48.8 & 91.1 & 2.0 & 25.6 \\
\hline $20 \mathrm{mg}$ & - & 100.0 & - & 15.1 & 34.3 & 8.2 & 58.1 & 53.7 \\
\hline $40 \mathrm{mg}$ & - & - & 100.0 & 16.1 & 12.3 & 0.7 & 39.9 & 19.3 \\
\hline $80 \mathrm{mg}$ & - & - & - & 68.8 & 4.7 & - & - & 1.5 \\
\hline \multicolumn{9}{|l|}{$\mathrm{CV}$ risk } \\
\hline High $^{a}$ & 25.9 & 28.0 & 43.6 & 28.4 & 40.0 & 27.9 & 29.6 & 30.6 \\
\hline Moderate $^{b}$ & 46.3 & 44.1 & 35.1 & 41.6 & 35.5 & 40.9 & 41.5 & 42.8 \\
\hline Low $^{c}$ & 27.8 & 27.9 & 21.3 & 30.0 & 24.5 & 31.2 & 28.9 & 26.7 \\
\hline \multicolumn{9}{|l|}{ Comorbidities } \\
\hline Coronary artery disease & 5.8 & 7.8 & 27.5 & 7.9 & 20.8 & 11.5 & 13.8 & 11.3 \\
\hline Familial hypercholesterolemia & 0.0 & 0.1 & 0.1 & 0.2 & 2.2 & 1.9 & 0.0 & 0.1 \\
\hline Diabetes & 20.7 & 21.0 & 17.8 & 20.8 & 20.6 & 15.2 & 18.6 & 20.2 \\
\hline Hypertension & 29.6 & 29.0 & 28.3 & 29.5 & 28.7 & 26.4 & 30.4 & 29.0 \\
\hline No other CV drugs ${ }^{\mathrm{d}}$ in use & 33.5 & 33.5 & 25.2 & 34.5 & 30.9 & 39.0 & 32.0 & 32.0 \\
\hline \multicolumn{9}{|l|}{$\begin{array}{l}\text { Changes in statin therapy during } 1 \text { year } \\
\text { following initiation }\end{array}$} \\
\hline No change & 63.4 & 68.9 & 73.6 & 56.3 & 61.0 & 68.0 & 52.6 & 67.9 \\
\hline Changed dose & 17.0 & 11.5 & 5.9 & 25.0 & 18.4 & 15.6 & 23.3 & 11.6 \\
\hline Changed to another statin & 6.9 & 7.8 & 11.3 & 5.7 & 10.8 & 5.2 & 10.3 & 9.0 \\
\hline Single prescription during the first year & 12.7 & 11.8 & 9.3 & 13.0 & 9.8 & 10.8 & 13.8 & 11.5 \\
\hline
\end{tabular}

SD, stardard deviation; CV=cardiovascular. Unless stated otherwise, data are given as percentages.

${ }^{a}$ Individuals with high CV risk were entitled to special reimbursement for drug treatment of coronary artery disease, diabetes or familial hypercholesterolemia, or had purchased clopidogrel (Anatomical Therapeutic Chemical [ATC] code B01AC04) or antidiabetic medications (A10) within one year prior to cohort entry. ${ }^{\mathrm{b}}$ Individuals with moderate $\mathrm{CV}$ risk did not meet the criteria for high-risk status but had purchased cardiovascular drugs (ATC codes B01, C01, C02, $\mathrm{C} 03, \mathrm{C} 07, \mathrm{C} 08, \mathrm{C} 09$ ) or were entitled to special reimbursement due to hypertension. ${ }^{\mathrm{c}}$ Individuals with low $\mathrm{CV}$ risk did not meet the criteria for high or moderate-risk status. ${ }^{\mathrm{d}}$ Refers to ATC groups B01, C01, C02, C03, C07, C08 and C09. 